Int. J. Curr. Res. Med. Sci. (2017). 3(4): 87-96

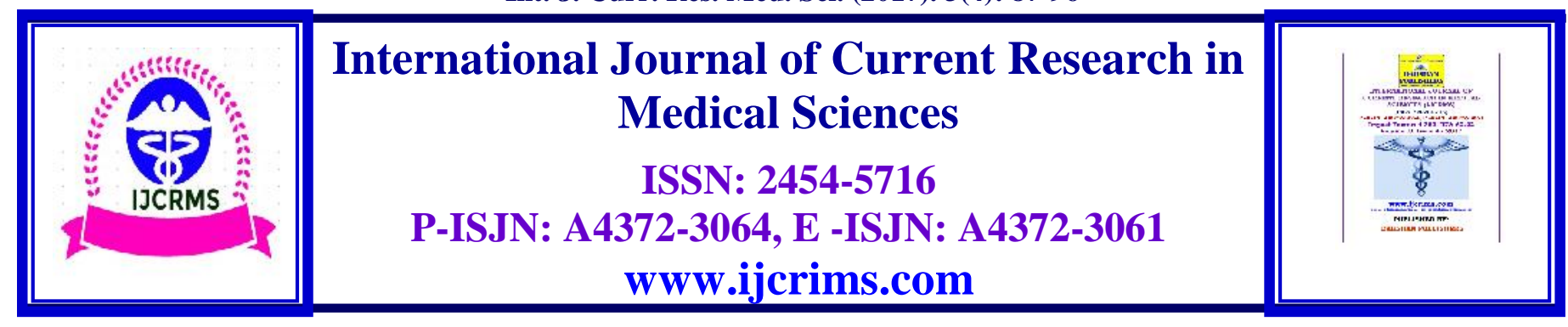

Original Research Article

Volume 3, Issue 4 -2017

DOI: http://dx.doi.org/10.22192/ijcrms.2017.03.04.014

\title{
Assessment of prevalence, knowledge, attitude and practices of obesity among college students in Sohag Governorate
}

\author{
Magda Mohamed Ali, Nayel Abd Elhamed Zaki \\ Departments of Community Medicine and Internal Medicine, Sohag Faculty of Medicine, \\ Sohag University, Sohag, Egypt \\ *Corresponding author: magdamohameda@yahoo.com
}

\begin{abstract}
Introduction: The WHO classifies about 400 million people around the world as obese. Obesity is the fifth leading cause for deaths all over the world. The prevalence of obesity has nearly doubled between 1980 and 2008.

The aims of this study were to: estimate the prevalence of obesity, study the KAP (knowledge, attitude and practice) among students studying at Sohag University and compare KAP between obese and non obese participants.

Subjects and Methods: A cross sectional study. This study was based on interviewing university students in the period from January 2015 to December 2015. A total of 961 students were included. A specially designed questionnaire was applied for all of the participants by KAP Model designed by Librahim in 1995 .

Results: Our study included 961 university students, mean age 19.5 \pm 1.5 years; equally divided into males and females. The prevalence of obesity among our study group was $17.2 \%$. No significant difference between obese and non obese students regarding age or sex. Diagnosis:36.4\% of them were by medical consultation, $29.1 \%$ by self notice, $18.8 \%$ by family and lastly $15.8 \%$ by other methods. The knowledge about obesity was assessed by two types of questions; the nature of obesity and its cause the vast majority of our participants thought that obesity is a hormonal disease, then psychological and an infectious disease. As the attitude, surprisingly, more of the obese persons thought that they should not marry or have children than the non obese ones, only about half of our obese persons thought that they can think like any normal person, compared to over $76 \%$ of the non obese persons had this belief; the difference is significant. As regards the practice towards obesity, less than half of the obese persons agreed to marry another obese one, while only $28 \%$ of the non obese persons agreed to do. We found that more of the non obese persons agreed to have friendship and/or to work with an obese person (53\%) compared to only (37\%) of the obese persons. The differences in the above three comparisons were statistically significant.

Conclusion: Obesity is a common and problematic health condition among Sohag University students. More effort should be done to improve the knowledge and attitude towards obesity.
\end{abstract}

Keywords: obesity, prevalence, KAP 


\section{Introduction}

Obesity is defined as abnormal or excessive fat accumulation in the body. This definition, although more accurate than just calculating the body mass index, is impracticable for epidemiological use. The body mass index (BMI) which is calculated by dividing weight (in kilograms) over the square height (in meters); is widely used in adult populations to assess overweight and obesity. The World Health Organization (WHO) defines overweight as a BMI equal to or more than 25 , and obesity as a BMI equal to or more than 30(1). The WHO classifies about 400 million people around the world as obese ${ }^{(1)}$.

Obesity is the fifth leading cause for deaths all over the world. Nearly 3 million adults die each year as a direct or indirect result of obesity (1). The prevalence of obesity has nearly doubled between 1980 and 2008. 65\% of the world's population lives in countries where overweight and obesity kills more people than underweight or starvation ${ }^{(2)}$.

Many factors contribute to the development of obesity. These include diet, genetic predisposition, physical activities, physiological and behavioural factors ${ }^{(3)}$. It is a major risk factor for type 2 diabetes mellitus, hypertension, stroke, coronary heart diseases, gall bladder diseases, arthritis, colon cancer, psychological problems and so on. Nevertheless, the social impact of obesity is a major problem but is often neglected. The socio-economic problems include lower academic success rate, poor job chances available and lower self confidence ${ }^{(4)}$.

Obesity among adolescents and early middle aged persons is rising for more than two decades $(5,6)$. About 15\% of adolescents (aged 12-19 years) in the united states are obese ${ }^{(7)}$. University students are more prone to obesity due to their lifestyle with less physical activity and disordered eating habits and thereby are prone to obesity related health hazards ${ }^{(8)}$.

\section{Aims of the study:}

\section{The aims of this study were to:}

1. To estimate the prevalence of obesity among Sohag University students.

2. To study the KAP (knowledge, attitude and practice) among students studying at Sohag University, towards obesity.

3. To compare KAP between obese and non obese participants.

\section{Subjects and Methods}

\section{Type of the study:}

A cross sectional study.

\section{Subjects:}

This study was based on interviewing university students of different colleges in Sohag University in the period from January 2015 to December 2015. A total of 961 students were included in the study.

$\mathrm{N}=(\mathrm{z} 1-\alpha / 2) 2 \quad \mathrm{P}(1-\mathrm{p}) / \mathrm{D} 2$ (Andrew, et.al 1998)

$\mathrm{N}=$ the desired sample size when population is more than 10.000 .

$\mathrm{P}=$ Prevalence of obesity (17,2in developing countries per 1000).

Z1- $\alpha=$ Represent the number of standard errors from the mean and it is equal 1.96 .

$\mathrm{D}=$ degree of accuracy desired usually at .05 .

So the calculated sample size was 961 students

\section{Methods:}

A specially designed questionnaire was applied for all of the participants, to assess the Knowledge, Attitude and Practice (KAP) according to the 1995 KAP Model designed by Librahim in $1995^{(9)}$.

\section{KAP model Definitions (9):}

Knowledge: Knowledge is the capacity to acquire, retain and use information; a mixtuequation of comprehension, experience, discernment and skill. 
Attitude: Attitude refers to inclinations to react in a certain way to certain situation; to see and interpret events according to certain predispositions; or to organize opinions into coherent and interrelated structure.

Practice: By Practice we mean the application of rules and knowledge that leads to action. Good practice is an art that is linked to the progress of knowledge and technology and is executed in an ethical manner.

\section{The questionnaire consisted of the following parts:}

Part 1: Who are you (to assess the prevalence of obesity among participants):

1. Age

2. Sex

3. Are you obese?

\section{Part 2: Diagnosis and treatment of obesity:}

1. How was your obesity diagnosed?

2. Do you take medications regularly?

\section{Part 3: Knowledge about obesity:}

1. Do you think that obesity is:
a) An infectious disease.
b) A psychological disease.
c) A hormonal disease.
d) A non treatable disease.

\section{Do you think that the cause of obesity}

is:

a) Hereditary.

b) Envy.

c) Stress.

d) Increased appetite.

e) Medications.

f) Punishment from Allah.

g) I do not know.

\section{Part 4: Attitude towards obesity:}

1. Do you think that obese patient should not marry?

2. Do you think that obese patient should not have children?
3. Do you think that obese patient can think like any normal person?

4. Do you think that obese patient can drive a car?

\section{Part 5: Practice}

1. Do you personally accept to marry an obese patient.

2. Do you personally accept to make friendship with an obese patient.

3. Do you personally accept to work with an obese patient.

4. Do you personally accept to have a picnic with an obese patient.

\section{Statistical analysis:}

Data was analysed using the IBM-SPSS software, version 24 (May 2016); IBM corporation, Chicago, USA.

Data was expressed as number and percentages for qualitative data; and mean and standard deviation for quantitative data.

Student $\mathrm{t}$ test was done to compare means of quantitative data, and Pearson chi square test was used to compare percentages of quantitative data.

\section{Ethical consideration}

The study was approved by the Ethical committee of the Faculty of Medicine- Sohag University. An informed written consent was taken from all participants in the study. All participants were reassured of data confidentiality.

\section{Results}

Our study included 961 university students, whose mean age is around $19.5 \pm 1.5$ years, with a range from 16-24 years. The study group was nearly equally divided into males and females. The prevalence of obesity among our study group was $17.2 \%$. No significant difference between obese and non obese students regarding age or sex (table 1). 
Int. J. Curr. Res. Med. Sci. (2017). 3(4): 87-96

Table 1. Sociodemographic data of the studied college students

\begin{tabular}{|c|c|c|c|c|c|c|}
\hline \multicolumn{3}{|c|}{ Question } & Obese & Non obese & $\begin{array}{c}\text { Chi } \\
\text { square*/ } \\
\text { T test } * *\end{array}$ & $\begin{array}{c}\mathbf{P} \\
\text { value }\end{array}$ \\
\hline 1. & Number & & $165(17.2 \%)$ & $796(82.8 \%)$ & - & - \\
\hline \multirow[t]{10}{*}{2.} & Age & Mean \pm SD & $19.57 \pm 1.58$ & $19.52 \pm 1.62$ & $0.386 * *$ & 0.699 \\
\hline & & 16 years & $1(0.6 \%)$ & $6(0.8 \%)$ & $2.989 *$ & 0.935 \\
\hline & & 17 years & $11(6.7 \%)$ & $66(8.3 \%)$ & & \\
\hline & & 18 years & $35(21.2 \%)$ & $178(22.4 \%)$ & & \\
\hline & & 19 years & $37(22.4 \%)$ & $164(20.6 \%)$ & & \\
\hline & & 20 years & $37(22.4 \%)$ & $164(20.6 \%)$ & & \\
\hline & & 21 years & $23(13.9 \%)$ & $110(13.8 \%)$ & & \\
\hline & & 22 years & $14(8.5 \%)$ & $84(10.6 \%)$ & & \\
\hline & & 23 years & $6(3.6 \%)$ & $17(2.1 \%)$ & & \\
\hline & & 24 years & $1(0.6 \%)$ & $7(0.9 \%)$ & & \\
\hline \multirow[t]{2}{*}{3.} & Sex & Male & $81(49.1 \%)$ & $384(48.2 \%)$ & $0.040 *$ & 0.842 \\
\hline & & Female & $84(50.9 \%)$ & $412(51.8 \%)$ & & \\
\hline
\end{tabular}

Regarding the diagnosis of obesity among the 165 obese person included in our study, $36.4 \%$ of them were diagnosed by medical consultation, $29.1 \%$ by self notice, $18.8 \%$ by family notice and lastly $15.8 \%$ by other methods. Slightly more than half of these obese persons were taking medications regularly (54.6\%) (figures 1 and 2).

\section{Do you take medications regularly?}

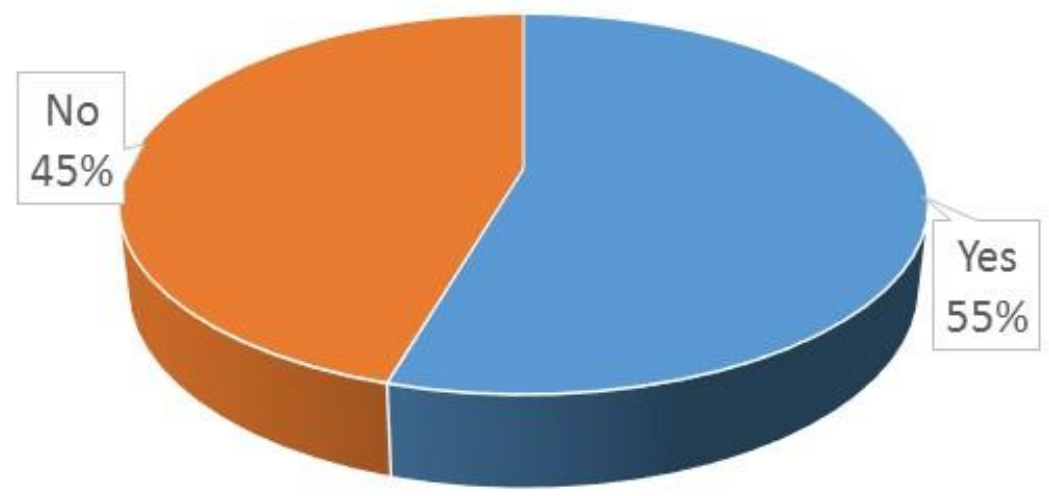

Figure 1. Do you take medications regularly? 
Int. J. Curr. Res. Med. Sci. (2017). 3(4): 87-96

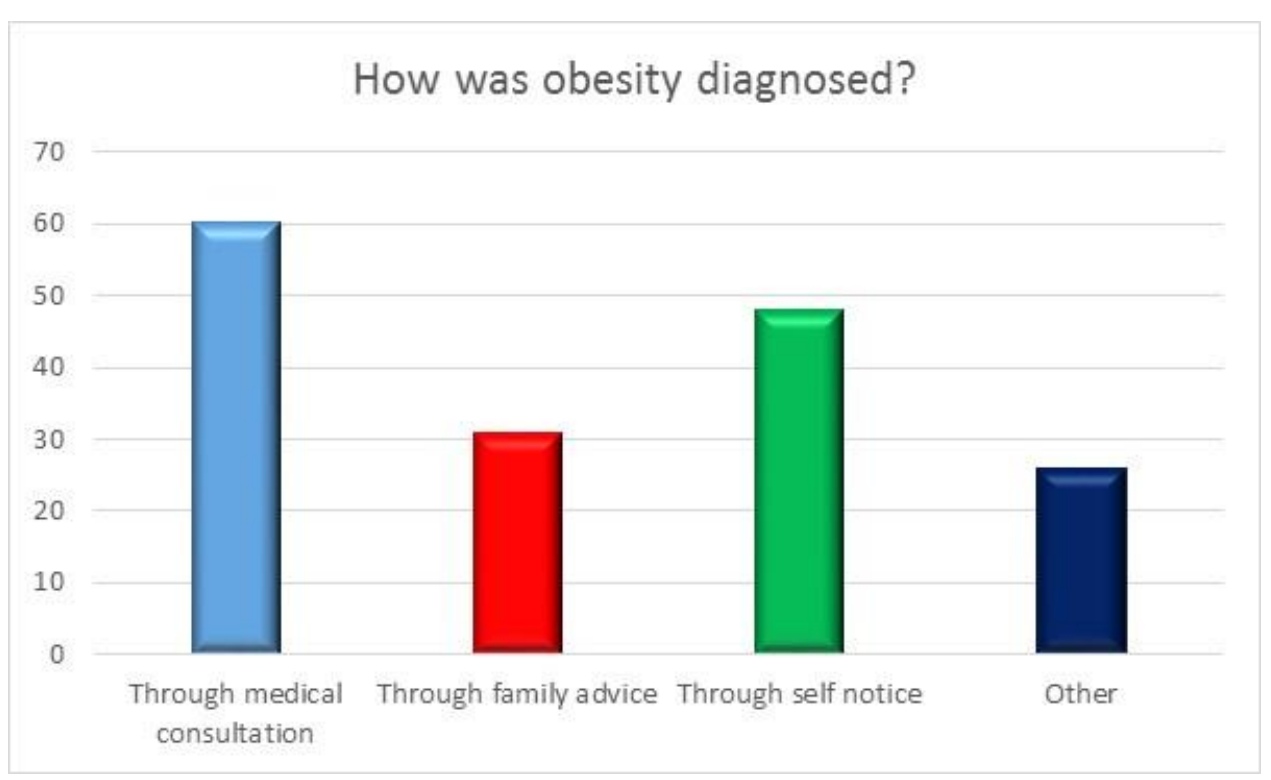

Figure 2. How was obesity diagnosed?

The knowledge of our study group about obesity was assessed by two types of questions; the nature of obesity and its cause. Regarding the nature of obesity, the vast majority of our participants thought that obesity is a hormonal disease, followed by those who thought that obesity is a non treatable disease, then those who believe that it is a psychological disease and lastly those who though that obesity is an infectious disease. Obese students believe more of psychological and non treatable natures of obesity than non obese persons (table 2).

Table 2. Knowledge of the studied college students

\begin{tabular}{|c|c|c|c|c|c|}
\hline \multicolumn{2}{|c|}{ Question } & \multirow{2}{*}{\begin{tabular}{|c|} 
Obese \\
$12(7.3 \%)$
\end{tabular}} & \multirow{2}{*}{$\begin{array}{l}\text { Non obese } \\
81(10.2 \%)\end{array}$} & \multirow{2}{*}{$\begin{array}{c}\text { Chi } \\
\text { square } \\
1.318\end{array}$} & \multirow{2}{*}{$\begin{array}{c}\begin{array}{c}\mathbf{P} \\
\text { value }\end{array} \\
0.251\end{array}$} \\
\hline Do you & An infectious disease & & & & \\
\hline \multirow[t]{3}{*}{$\begin{array}{c}\text { think that } \\
\text { obesity? }\end{array}$} & $\begin{array}{c}\text { A psychological } \\
\text { disease }\end{array}$ & $26(15.8 \%)$ & $76(9.5 \%)$ & 5.555 & 0.018 \\
\hline & A hormonal disease & $72(43.6 \%)$ & $510(64.1 \%)$ & 23.893 & $<0.001$ \\
\hline & $\begin{array}{c}\text { A non treatable } \\
\text { disease }\end{array}$ & $55(33.3 \%)$ & $129(16.2 \%)$ & 25.898 & $<0.001$ \\
\hline \multirow{7}{*}{$\begin{array}{l}2 . \quad \text { Do you } \\
\text { think that the } \\
\text { cause of obesity } \\
\text { is }\end{array}$} & Hereditary & $10(6.1 \%)$ & $11(1.4 \%)$ & 13.997 & $<0.001$ \\
\hline & Envy & $33(20 \%)$ & $68(8.5 \%)$ & 19.075 & $<0.001$ \\
\hline & Stress & $85(51.5 \%)$ & $532(66.8 \%)$ & 13.955 & $<0.001$ \\
\hline & Increased appetite & $10(6.1 \%)$ & $8(1 \%)$ & 19.005 & $<0.001$ \\
\hline & Medications & $1(0.6 \%)$ & $5(0.6 \%)$ & 0.001 & 0.975 \\
\hline & $\begin{array}{l}\text { Punishment from } \\
\text { Allah }\end{array}$ & 0 & $2(0.3 \%)$ & 0.415 & 0.519 \\
\hline & I do not know & $26(15.8 \%)$ & $170(21.4 \%)$ & 2.639 & 0.104 \\
\hline
\end{tabular}

Regarding the causes of obesity, most of our participants believe that stress is the cause of obesity, with significantly higher percentage among non obese persons $(66.8 \%)$ compared to obese ones $(51.5 \%)$. On the other hand, more obese students believe of other factors as possible causes of obesity (envy, heredity and/or increased appetite) than non obese ones (table 2). 
Regarding the attitude of our study people towards obesity. Most of our participants stated that obese persons can marry and have children as usual with no limitations. Surprisingly, more of the obese persons thought that they should not marry or have children than the non obese ones, with significant differences. On the other hand, only about half of our obese persons thought that they can think like any normal person, compared to over $76 \%$ of the non obese persons had this belief; the difference is significant. Also, nearly half of the non obese persons believed that obese person can drive a car, while only $32.7 \%$ of the obese persons believe that they can drive a car. The difference is, again, significant (table 3).

Table 3. Attitude of the studied college students

\begin{tabular}{|c|c|c|c|c|c|}
\hline \multicolumn{2}{|l|}{ Question } & \multirow{2}{*}{$\begin{array}{c}\text { Obese } \\
29(17.6 \%)\end{array}$} & \multirow{2}{*}{$\begin{array}{l}\text { Non obese } \\
69(8.7 \%) \\
\end{array}$} & \multirow{2}{*}{$\begin{array}{c}\begin{array}{c}\text { Chi } \\
\text { square }\end{array} \\
39.775\end{array}$} & \multirow{2}{*}{$\begin{array}{c}\begin{array}{c}P \\
\text { value }\end{array} \\
<0.001\end{array}$} \\
\hline 1. Do you think & Yes & & & & \\
\hline that obese patient & No & $82(49.7 \%)$ & $592(74.4 \%)$ & & \\
\hline should not marry & $\begin{array}{l}\text { I do not } \\
\text { know }\end{array}$ & $54(32.7 \%)$ & $135(17 \%)$ & & \\
\hline \multirow{3}{*}{$\begin{array}{l}2 . \quad \text { Do you think } \\
\text { that obese patient } \\
\text { should not have } \\
\text { children }\end{array}$} & Yes & $24(14.5 \%)$ & $77(9.7 \%)$ & 21.571 & $<0.001$ \\
\hline & No & $84(50.9 \%)$ & $554(69.6 \%)$ & & \\
\hline & $\begin{array}{l}\text { I do not } \\
\text { know }\end{array}$ & $57(34.5 \%)$ & $165(20.7 \%)$ & & \\
\hline \multirow{3}{*}{$\begin{array}{l}\text { 3. Do you think } \\
\text { that obese patient can } \\
\text { think like any normal } \\
\text { person }\end{array}$} & Yes & $92(55.8 \%)$ & $611(76.8 \%)$ & 32.196 & $<0.001$ \\
\hline & No & $24(14.5 \%)$ & $49(6.2 \%)$ & & \\
\hline & $\begin{array}{l}\text { I do not } \\
\text { know }\end{array}$ & $49(29.7 \%)$ & $136(17.1 \%)$ & & \\
\hline \multirow{2}{*}{$\begin{array}{l}\text { 4. Do you think } \\
\text { that obese patient can } \\
\text { drive a car }\end{array}$} & Yes & $54(32.7 \%)$ & $387(48.6 \%)$ & 14.276 & $<0.001$ \\
\hline & $\begin{array}{l}\text { No } \\
\text { I do not } \\
\text { know }\end{array}$ & $\begin{array}{c}50(30.3 \%) \\
61(37 \%)\end{array}$ & $\begin{array}{l}172(21.6 \%) \\
237(29.8 \%)\end{array}$ & & \\
\hline
\end{tabular}

As regards the practice of our study population towards obesity, we found that a little less than half of the obese persons agreed to marry another obese one, while only $28 \%$ of the non obese persons agreed to do so. Opposite to the acceptance to marry an obese person, we found that more of the non obese persons agreed to have friendship and/or to work with an obese person
(53\%) compared to only (37\%) of the obese persons. The differences in the above three comparisons were statistically significant. Lastly, the majority of our participants answered with (I do not know) when asked about having a picnic with an obese person, and this was similar in the two groups, with non significant difference (table 4). 
Int. J. Curr. Res. Med. Sci. (2017). 3(4): 87-96

Table 4. Practice of the studied college students

\begin{tabular}{|c|c|c|c|c|c|}
\hline Question & & Obese & Non obese & & $\mathbf{P}$ \\
\hline $\begin{array}{l}\text { 1. Do you personally } \\
\text { accept to marry an obese } \\
\text { patient }\end{array}$ & $\begin{array}{l}\text { Yes } \\
\text { No } \\
\text { I do not } \\
\text { know }\end{array}$ & $\begin{array}{l}69(41.8 \%) \\
55(33.2 \%) \\
41(24.8 \%)\end{array}$ & $\begin{array}{c}226(28.4 \%) \\
479(60.2 \%) \\
91(11.4 \%)\end{array}$ & 43.657 & $<0.001$ \\
\hline $\begin{array}{l}\text { Do you personally } \\
\text { accept to make } \\
\text { friendship with an obese } \\
\text { patient }\end{array}$ & $\begin{array}{l}\text { Yes } \\
\text { No } \\
\text { I do not } \\
\text { know }\end{array}$ & $\begin{array}{c}61(37 \%) \\
58(35.2 \%) \\
46(27.8 \%)\end{array}$ & $\begin{array}{l}425(53.4 \%) \\
287(36.1 \%) \\
84(10.5 \%)\end{array}$ & 37.648 & $<0.001$ \\
\hline $\begin{array}{l}\text { 3. Do you personally } \\
\text { accept to work with an } \\
\text { obese patient }\end{array}$ & $\begin{array}{l}\text { Yes } \\
\text { No } \\
\text { I do not } \\
\text { know }\end{array}$ & $\begin{array}{l}59(35.8 \%) \\
64(38.8 \%) \\
42(25.5 \%)\end{array}$ & $\begin{array}{l}425(53.4 \%) \\
284(35.7 \%) \\
87(10.9 \%)\end{array}$ & 30.284 & $<0.001$ \\
\hline $\begin{array}{l}\text { 4. Do you personally } \\
\text { accept to have a picnic } \\
\text { with an obese patient }\end{array}$ & $\begin{array}{l}\text { Yes } \\
\text { No } \\
\text { I do not } \\
\text { know }\end{array}$ & $\begin{array}{c}10(6.1 \%) \\
16(9.7 \%) \\
139(84.2 \%)\end{array}$ & $\begin{array}{l}74(9.3 \%) \\
81(10.2 \%) \\
641(80.5 \%)\end{array}$ & 1.901 & 0.387 \\
\hline
\end{tabular}

\section{Discussion}

Nowadays, increased prevalence of overweight and obesity is noted among, all age groups in both genders. our study results indicated that the prevalence of overweight and obesity among the sample $(\mathrm{n}=961)$ of students from Sohag University were $34.9 \%$ and $17.2 \%$ respectively.

Based on BMI classification of weight status, finding of this study indicate that more than half of students $55.3 \%$ were of normal weight.

Furthermore, the results of this study are in agreement with several studies in Arab countries. in Lebanon a study conducted in 2008, the prevalence of overweight and obesity among students of Lebanese American University were found to be more common among male students compared to females $37.5 \%$ and $12.5 \%$ vs $13.6 \%$ and $3.2 \%$ respectively.

In a study conducted on University students in Bahrain, the proportion of obesity were (11.8\% in males and $7.6 \%$ in females). High prevalence rates of overweight and obesity was also reported in a study conducted in Kuwait university (32\% and $8.9 \%$ respectively).

In 2003 , WHO identified that $(23.5 \%)$ of east Mediterranean, (25.5\%) of European and 10.6\% southeast Asian of children and adolescents were reported either overweight or obese.

Regarding food habits, university students often select fast food due to its palatability, availability and convenience. They usually do not follow healthy eating habits as diet is high in fat and low in fruits and vegetables. American Dietetic Association (ADA) indicates that obesity or overweight is a fast food related issue.

Improving students knowledge about nutrition and healthy eating habits may promote healthy body weight management among students.

A study conducted among college students reported that increased knowledge of dietary guidance, dietary guidelines for Americans 2005, appeared to be positively related to more healthy eating pattern thus the better eaters had a higher level of knowledge about nutrition. 
In general, it is well known that, low levels of physical activity, sedentary habits, high protein and sugar intakes, low fiber consumption and frequent snaking contribute to the high prevalence of overweight and obesity.

Our results were matching with many results in different studies in other countries considering inverse proportion between physical activity and prevalence of overweight and obesity.

Our results were in agreement with the obtained results from USA in a study conducted by Mary Story, 2001, where the majority of the respondents $(59 \%)$ were doing exercise ${ }^{(10)}$.

In addition mean BMI has been found to be increased with decreased physical activity level.

In our results, $(67.4 \%)$ of overweight and $(81 \%)$ of obese students were of low activity level, while $(62.7 \%)$ of students with normal BMI were of high activity levels.

The results of the present study were in disagreement with the reported results from some Arab countries. In a study conducted in Saudi Arabia (2003), Al-Rukban found that $13.8 \%$ and $20.5 \%$ of Saudi male adolescents in Riyadh had got overweight and obesity respectively (11). In Sharjah Emirate in academic year (1998-1999), Alwan reported a prevalence of obesity among preparatory and secondary school students to be $8.9 \%$ and the overweight was $15.8^{(12) \text {. }}$

The higher prevalence of overweight $\&$ obesity in the Gulf countries could be explained by the higher socioeconomic status and more civilized life. Also, the availability of different varieties of food staff, fast food and over-nutrition leads to increase of trend of obesity. High prevalence of energy-saving technology in the child's home plays another cause of obesity in Gulf countries. The hot weather may have an influence in term of increasing use of transportation and a greater decline in the level of physical activity. These issues were emphasized generally by some authors (13).
Concerning obesity in the developed countries, the results of the present study were in disagreement with the reported results from western countries. In USA; data from National Health and Nutrition Examination Surveys had shown that for adolescents aged 12 to 19 years, prevalence increased from $5.0 \%$ to $17.6 \%{ }^{(14) \text {. }}$

Regarding the attitude of our study people towards obesity. Most of our participants stated that obese persons can marry and have children as usual with no limitations. Surprisingly, more of the obese persons thought that they should not marry or have children than the non obese ones, with significant differences.

On the other hand, only about half of our obese persons thought that they can think like any normal person, compared to over $76 \%$ of the non obese persons had this belief; the difference is significant. Also, nearly half of the non obese persons believed that obese person can drive a car, while only $32.7 \%$ of the obese persons believe that they can drive a car. The difference is, again, significant.

As regards the practice of our study population towards obesity, we found that a little less than half of the obese persons agreed to marry another obese one, while only $28 \%$ of the non obese persons agreed to do so. Opposite to the acceptance to marry an obese person, we found that more of the non obese persons agreed to have friendship and/or to work with an obese person (53\%) compared to only (37\%) of the obese persons. The differences in the above three comparisons were statistically significant. Lastly, the majority of our participants answered with (I do not know) when asked about having a picnic with an obese person, and this was similar in the two groups, with non significant difference.

The effect of marriage on weight status has been found in other studies ${ }^{(15,16)}$ and could be due to cultural expectations whereby weight reflects happiness and contentment after marriage. Nepalese cultural etiquette also dictates generosity, particularly in providing overflowing food portions for guests ${ }^{(17)}$ possibly as a show of prosperity. The association of weight status with 
actual prosperity in the form of a senior post, seen here, has also been highlighted in a recent study conducted among civil servants in Ghana ${ }^{(18) .}$

Our results were in partial agreement with the reported results from other studies addressing the relation between overweight and depressive symptoms. Strauss surveyed 1,520 children, ages 9-10, with a four-year follow up and discovered a positive correlation between obesity and low self esteem. He also discovered that decreased self esteem lead to a considerable proportion (19\%) of obese children are feeling sad, $48 \%$ of them feeling bored and $21 \%$ of them feeling nervous. About eight percent of normal weight children felt sad, $42 \%$ of them felt bored, and $12 \%$ of them felt nervous ${ }^{(19)}$.

\section{Conclusion}

Obesity is a common and problematic health condition among Sohag University students. However, more effort should be done by health care givers to improve the knowledge and attitude of these students towards obesity.

\section{References}

1. WHO. Obesity and overweight. Available at:

2. http://wwwwhoint/mediacentre/factsheets/fs31 1/en/. 2013.

3. WHO. 10 facts on obesity. Available at: http://wwwwhoint/ features/factfiles/obesity/en/. 2013.

4. Wilborn C, Beckham J, Campbell B, Harvey T, Galbreath M, La Bounty P, et al. Obesity: prevalence, theories, medical consequences, management, and research directions. Journal of the International Society of Sports Nutrition. 2005;2:4-31.

5. Visscher TL, Seidell JC. The public health impact of obesity. Annual review of public health. 2001;22:355-75.

6. Batch JA, Baur LA. 3. Management and prevention of obesity and its complications in children and adolescents. The Medical journal of Australia. 2005;182(3):130-5.

7. Ibrahim A. Assessment of prevalence of obesity among school children age group 6 to
18 years in Ismailia city. Master thesis Suez Canal University Pediatric Departement. 2008.

8. American Academy of Pediatrics Committee on Adolescence. Active healthy living: prevention of childhood obesity through increased physical activity. . 2007.

9. Deotale MK, Ranganathan U, Akarte SV. Prevalence of overweight and obesity among medical students and their knowledge, attitude and practices about obesity. International Journal of Scientific Reports. 2015 (May);1(1):74-9.

10. Librahim G. Knowledge, attitude and practice the three pillars of excellence and wisdom: a place in the medical profession. Eastern Mediterranean Health Journal. 1995;1(1):8-16.

11. Mary Story A. Assessment of the American Indian children thoughts regarding obesity, 2001;40(3):90-94.

12. Al-Rukban MO. Obesity among Saudi male adolescents in Riyadh, Saudi Arabia. Saudi MedicalJournal, 2003; 24(1):27-33.

13. Alwan AH, El-Awady MY, Radwan M\& Khella AK. Epidemiology of obesity among preparatory and secondary students attending Sharjah schools. Egyptian Journal of Community Medicine 2000; 17(3): 13-26.

14. Salmon J, Timperio A. "Prevalence, trends and environmental influences on child and youth physical activity". Med Sport Sci. 2007; 50: 183-99.

15. National Health and Nutrition Examination Surveys (NHANES) 1976 to 1980 and 2003 to 2006.

16. Janghorbani M, Amini M, Rezvanian H, et al. Association of body mass index and abdominal obesity with marital status in adults. Arch Iran Med. 2008;11:274-281.

17. Qidwai W, Azam SI. Knowledge, attitude and practice regarding obesity among patients, at Aga Khan University Hospital, Karachi. J Ayub Med Coll Abbottabad. 2004;16:32-34.

18. Smith C. Prevalence of obesity and contributing factors among Sherpa women in urban and rural Nepal. Am J Hum Biol. 1998;10:519-528. 
19. Addo J, Smeeth L, Leon DA. Obesity in urban civil servants in Ghana: association with pre-adult wealth and adult socio-economic status. Public Health. 2009;123:365-370.

20. Strauss RS. "Childhood obesity and selfesteem". 2002. Pediatrics 105 (1):15.

\begin{tabular}{|c|l|}
\hline \multicolumn{2}{|c|}{ Access this Article in Online } \\
\hline Q & Website: \\
\hline & www.ijcrims.com \\
& Subject: \\
\hline Quick Response Code & \\
\hline
\end{tabular}

How to cite this article:

Magda Mohamed Ali, Nayel Abd Elhamed Zaki. (2017). Assessment of prevalence, knowledge, attitude and practices of obesity among college students in Sohag Governorate. Int. J. Curr. Res. Med. Sci. 3(4): 87-96.

DOI: http://dx.doi.org/10.22192/ijcrms.2017.03.04.014 